\title{
Introduction and Evaluation of Tomato Germplasm by Participatory Mother and Baby Trials in the Morogoro Region of Tanzania
}

\author{
Anna L. Testen \\ Department of Plant Pathology, Ohio Agricultural Research and Development \\ Center, The Ohio State University, 1680 Madison Avenue, Wooster, OH 44691 \\ Delphina P. Mamiro, Hosea D. Mtui, and Jackson Nahson \\ Department of Crop Science and Horticulture, Sokoine University of Agriculture, \\ Morogoro, Tanzania
}

Ernest R. Mbega

Ilonga Agricultural Research Institute, Tanzanian Ministry of Agriculture, Kilosa, Tanzania

David M. Francis

Department of Horticulture and Crop Science, Ohio Agricultural Research and Development Center, The Ohio State University, 1680 Madison Avenue, Wooster, $\mathrm{OH} 44691$

Sally A. Miller
Department of Plant Pathology, Ohio Agricultural Research and Development
Center, The Ohio State University, 1680 Madison Avenue, Wooster, OH 44691

Additional index words. participatory variety selection, international agriculture, variance partitioning, Solanum lycopersicum

\begin{abstract}
Tomato is an important cash crop in many developing countries. However, smallholder farmers often lack access to improved cultivars and breeding programs to develop locally adapted cultivars are limited. Participatory crop improvement (PCI) approaches can be used to increase farmer access to improved cultivars. In this project, we used the mother and baby trial (MBT) design to introduce and evaluate tomato cultivars in three villages in the Morogoro Region of Tanzania. Mother trials were conducted in seven environments within the three villages, and variance partitioning revealed significant genetic effects for all traits measured with $h^{2}$ ranging from 0.74 to 0.90 for yield and disease reaction, respectively. In baby trials, farmers provided qualitative rankings of cultivars for 16 characteristics, including vigor, yield, harvest period, diseases, insect damage, fruit quality, and salability. Results from baby trials indicated that introduced cultivars were locally acceptable to farmers, except for traits related to marketability. Outcome Mapping was used to evaluate progress in each of the three villages and results suggested that high stakeholder participation levels could predict future adoption of introduced cultivars. Our findings provide a framework for evaluating, selecting, and breeding tomato and other horticultural crops in developing countries using the MBT design for PCI.
\end{abstract}

Vegetable crops serve as an important source of income and nutrients for smallholder farm families in developing countries. In Tanzania, tomato (Solanum lycopersicum L.)

Received for publication 8 Sept. 2016. Accepted for publication 7 Oct. 2016.

This research was funded by the U.S. Agency for International Development Feed the Future Initiative through a collaborative research grant award no. 621-A-00-11-00009-00 from the Innovative Agricultural Research Initiative (iAGRI) and a U.S. Borlaug Fellows in Global Food Security graduate student research grant to Ms. Testen.

${ }^{1}$ Corresponding author. E-mail: miller.769@osu.edu. is one of the most commonly grown vegetables. Tomato yields in Tanzania are constrained by diseases, insect pests, poor soils, limited inputs, and limited farmer access to improved cultivars (Maerere et al., 2010; Minja et al., 2011; Ojiewo et al., 2011). Tomato is a key cash crop in the Morogoro Region of Tanzania (Paavola, 2008; Ponte, 1998). Determinate, inbred, plum-type tomato cultivars, such as Roma, Tanya, Onyx, and Cal J are commonly grown, whereas hybrid cultivars are rarely produced (Asiimwe et al., 2013; Maerere et al., 2006). Farmer access to cultivars is limited to those available from local agricultural input dealers. One means to increase farmers' access and openness to new tomato cultivars is through participatory variety selection (PVS) trials.

PCI methods, including PVS and participatory plant breeding (PPB), are powerful tools to introduce and evaluate new crop cultivars (Almekinders and Elings, 2001). PVS and PPB are particularly useful for providing smallholder farmers access to and experience with new cultivars. In PPB, farmers are included in evaluating and selecting germplasm from segregating populations, whereas in PVS, farmers evaluate and select from established cultivars (Witcombe et al., 2005). In participatory approaches, farmers are immediately engaged in the crop selection process, which helps in adoption by identifying desired crop traits early and providing farmers experience with different cultivars (Witcombe et al., 2005). PCI approaches have been used to evaluate components of cropping systems including grains (Belay et al., 2006; Witcombe et al., 1999), legumes (Kitch et al., 1998; Sperling et al., 1993), fruits (Akinnifesi et al., 2004; Leakey et al., 2003), vegetables (Pandey et al., 2006; Thiele et al., 1997), and underrepresented indigenous crops (Diouf et al., 2007; McElhinny et al., 2006). In Tanzania, PCI has been applied to the evaluation and improvement of cultivars of maize (Bänzinger and Diallo, 2004), rice (Kafiriti et al., 2003), pigeonpea (Shiferaw et al., 2008), bean (Hillocks et al., 2006), groundnut (Osiru et al., 2009), amaranth (Adeniji and Aloyce, 2013), sorghum (Bucheyeki et al., 2010), cassava (Kundy et al., 2014; Waal et al., 1997), sweetpotato (Masumba et al., 2005), african eggplant (Adeniji and Aloyce, 2012), mustard (Adeniji and Aloyce, 2014), and cabbage (Adeniji et al., 2010). PVS was used to evaluate and introduce late blightresistant tomato cultivars at several sites across Tanzania (Ojiewo et al., 2011). For PCI in Tanzania, the level of farmer inclusion and overall trial design differ dramatically due to the requirements of the cropping system and project resources. One PCI approach that shows great promise is the MBT design, due to its high levels of farmer inclusion.

MBTs were originally developed as a means of participatory evaluation of soil fertility management practices in Malawi (Snapp, 1999; Snapp et al., 2002). Two types of trials are included in the MBT design: large, replicated, researcher-led mother trials and smaller nonreplicated, farmer-led trials. Mother trials consist of fewer, fully replicated experiments (such as randomized complete block) in which all treatment levels are compared and quantitative data on these treatments are gathered. Baby trials are conducted by farmers, who compare their local practices/cultivar to a subset of the tested treatments and provide qualitative, and sometimes quantitative data. These trials are run simultaneously in a single location (often a village) and researchers gain insight into the performance and local acceptability of introduced technologies, whereas farmers gain experience with them. MBT have been adapted for conducting PCI trials. A benefit of MBT for PPB and PVS is the inclusion of many different environments (both farmer practices and physical environments) to evaluate crop 
performance (Bänzinger and Diallo, 2004). MBTs have been used mainly in participatory breeding of grains including maize (Bänzinger and Diallo, 2004) and rice (Atlin et al., 2002). We know of no reports of the use of MBT for PCI for vegetables in developing countries.

To ensure the success of PCI projects, participation by project stakeholders should be evaluated to coordinate between and track progress at multiple project sites, while also identifying possible constraints to the project. Outcome Mapping, a technique first developed and used by the International Development Research Center (Earl et al., 2001), provides a means to develop and evaluate PCI projects. Instead of trying to assess long-term impacts due to the project, changes in participants' behaviors and actions are tracked during the course of the project and used as a measure of long-term project success. These changes are evaluated using progress markers, which are sets of anticipated behaviors and actions associated with a specific measure for project success, known as an outcome challenge (Earl et al., 2001). Outcome Mapping requires project leaders to work closely with project participants, known as boundary partners, to observe behaviors and actions, and the participatory nature of MBT allows for these observations to be made.

Our objectives were to introduce and evaluate new tomato germplasm through MBT in the Morogoro Region of Tanzania. These trials provide a framework for implementing and evaluating MBT as a means of both PPB and PVS for horticultural crops in developing countries. The findings of our study provide practical suggestions for using MBT in PCI for horticultural crops.

\section{Materials and Methods}

Baseline tomato production survey, site, and farmer selection. Baseline surveys were conducted to determine common characteristics of tomato farmers, tomato production practices, and constraints in five villages in the Morogoro Region: Msufini (6 $6^{\circ} 17^{\prime} 29.16^{\prime \prime} \mathrm{S}$, $\left.37^{\circ} 28^{\prime} 19.92^{\prime \prime} \mathrm{E}\right)$, Mabana (6²8'17.94" $\mathrm{S}$, $\left.37^{\circ} 25^{\prime} 34.62^{\prime \prime} \mathrm{E}\right)$, Msongozi $\left(7^{\circ} 4^{\prime} 10.20^{\prime \prime} \mathrm{S}\right.$, $\left.37^{\circ} 20^{\prime} 39.12^{\prime \prime} \mathrm{E}\right)$, Mlali $\left(6^{\circ} 57^{\prime} 39.60^{\prime \prime} \mathrm{S}\right.$, $\left.37^{\circ} 32^{\prime} 11.64^{\prime \prime} \mathrm{E}\right)$, and Kibagala $\left(7^{\circ} 6^{\prime} 12.78^{\prime \prime} \mathrm{S}\right.$, $37^{\circ} 35^{\prime} 9.96^{\prime \prime} \mathrm{E}$ ). Twenty tomato farmers were interviewed in Kiswahili in each village to gather information on farmers' socioeconomic status and tomato production practices including cultivar selection, agronomic practices, pest management practices, and marketing. Question types included free response, multiple selection, and ranking questions. This research was reviewed and approved for exempt status by the Ohio State University Institutional Review Board under protocol numbers 2013E0502 and 2014E0219. On the basis of the survey results, three villages were selected for PVS trials: Msufini, Mabana, and Msongozi. These villages differed in agroclimatic conditions and dominant soil types. Participating farmers were identified by village leaders and invited to join the trials.

Tomato cultivars. Seven local cultivars were compared with three introduced test lines. Local cultivars were selected from those commonly grown in the Morogoro Region and included 'Onyx', 'Mwanga', 'Tanya', 'Cal J', 'Assila F ' (Seminis, Monsanto Kenya, Nairobi, Kenya), 'Roma', and 'Tengeru 97.' The three introduced test lines for these trials were ' $\mathrm{OH} 8243$ ' [Ohio State University, OSU (Berry and Gould, 1988)], 'OH7870' [OSU (Berry and Gould, 1982)], and 'MT56' [OSU/Makerere University (Asiimwe et al., 2013)]. 'OH8243' and 'OH7870' are inbred lines developed for the tomato processing industry in the U.S. Midwest. They are determinate and plum-shaped, with characteristics of local tomato cultivars grown for fresh markets in Tanzania. 'MT56' produces a softer, larger, rounder fruit than the processing types. 'OH8243' and 'OH7870' were also selected for high levels of general foliar disease resistance and 'MT56' for a high level of resistance to bacterial wilt caused by Ralstonia solanacearum (Asiimwe et al., 2013). The introduced cultivars are all available in the public domain ('OH7870': OSU; 'OH8243': Plant Variety Protection certificate 8700143, expired 2007, National Plant Germplasm System PI 601423; and 'MT56': Makerere University) and represent more contemporary germplasm than is currently used in the region.

Trial design. The MBT design was adapted for these studies. Three mother trials were established in each of three villages in a randomized complete block design with three replicates of each cultivar. Ten baby trials were conducted in Msongozi and Mabana, and eleven were conducted in Msufini. Baby trials were established in a completely randomized design with no cultivar replication, and each individual trial served as an individual replicate in data analysis. In baby trials, farmers compared their local preferred cultivars to the three test cultivars.

Nursery establishment and field layout. Tomato seedling nurseries were established in all villages. Raised beds $(\approx 1 \times 10 \mathrm{~m})$ were prepared by hand for each cultivar. Cut foliage of dry local grasses was placed on beds and burned before planting. Seeds were planted in 2-cm-deep furrows, diammonium phosphate was applied in furrow, and furrows were lightly covered with soil. Beds were covered with dry grasses and watered until seedlings emerged. Seedlings were transplanted into field trials $\approx 3$ weeks after sowing.

Mother trial establishment. Mother trials were laid out in randomized complete block designs with three replications per cultivar. Each plot $(2.8 \times 3.5 \mathrm{~m})$ contained 30 plants, and rows and plants were spaced $0.7 \mathrm{~m}$ apart. The trials were kept weed free by hand weeding. Each mother trial was managed by a single farmer according to local management practices. Each mother trial represented a unique environment of soil characteristics and farmer management practices.

Mother trial evaluation. Soil characteristics in mother trial fields were evaluated from a composite soil sample consisting of 20 , 15-cm-deep samples from each mother trial field. Soil samples were analyzed at Sokoine University of Agriculture Soil Science Laboratory for $\mathrm{pH}$ (1:2.5 in water), electrical conductivity (1:2.5 in water), texture: Bouyoucos hydrometer method (Day, 1965), organic carbon: Walkley-Black method (Nelson and Sommers, 1996), total nitrogen: modified Kjeldahl method (Wilke, 2005), phosphorus: Bray 1 method (Bray and Kurtz, 1945), exchangeable potassium, exchangeable calcium, exchangeable magnesium, and exchangeable sodium: $1 \mathrm{~m}$ ammonium acetate extractant (pH 7.0) with quantification in an atomic absorption spectrometer (Sumner and Miller, 1996)).

Trials were evaluated at midseason, 10 weeks following sowing in Msongozi and Mabana, and 12 weeks following sowing in Msufini, and at the end of season 16, 18, and 20 weeks postsowing in Msongozi, Mabana, and Msufini, respectively. Evaluations within plots were conducted on the central 12 plants. At midseason, trials were assessed for vigor, stand count, percentage flowering/fruiting, insect damage, overall foliar disease severity, and incidence (number of plants exhibiting symptoms of that disease) and severity (percent of leaf area affected) of foliar diseases. At season's end, mother trials were evaluated for insect damage, overall foliar disease severity, and incidence and severity of foliar diseases. The most common disease was early blight (Alternaria sp.), but viral diseases, bacterial spot (Xanthomonas sp.) and speck (Pseudomonas sp.), and Septoria leaf spot (Septoria lycopersici) were also included in evaluations. Yield data were collected throughout the season $(\mathrm{kg} / \mathrm{plant})$. The number of buckets of fruit harvested in each plot was recorded and converted to yielded mass by multiplying by the average mass of a full bucket.

Baby trial establishment. Baby trials were laid out in a completely randomized, nonreplicated design with one farmer-selected local cultivar and the three introduced test cultivars. Each trial contained one $3.5 \times 3.5 \mathrm{~m}$ plot of each cultivar and each plot contained 30 plants.

Baby trial evaluation. Cultivars in baby trials were evaluated based on farmers' rankings collected in individually administered questionnaires at the end of the growing season. Farmers were asked to rank the four cultivars on 16 characteristics: crop vigor, ease of management, yield, first to harvest, harvest period, diseases, insect damage, fruit quality for eating, fruit quality for food preparation, fruit quality for marketing, fruit size, fruit color, fruit storage quality, salability, profitability, and overall preference. Cultivars were ranked 1-4 with no ties in the given rankings. Farmers also provided information on cultivar selection, preferred cultivar traits, and intent to adopt cultivars in these end of season surveys.

Outcome Mapping. Participation was evaluated in this project for three boundary partners: farmers, extensions agents, and village leaders. Progress markers were used to track changes in participants' actions and behaviors that were indicative that the program was succeeding. The majority of progress markers were evaluated three times: early, middle, and late, during the trials. Progress markers were also evaluated based on participation levels with "low participation" meaning that less than $50 \%$ 
of participants attended or an individual boundary partner was present at less than $50 \%$ of events, "moderate participation" if $50 \%$ to $75 \%$ of participants attended events or an individual partner attended $50 \%$ to $75 \%$ of events, and high if participation levels were greater than $75 \%$. Ratings for progress markers with participation levels were assigned a value of 1 to 3 for low to high, respectively. There were also several progress markers that were evaluated

Cultivar adoption and dissemination. One year following the conclusion of the project, farmers were interviewed in all three participating villages to determine if they had adopted or disseminated any of the introduced cultivars.

Statistical evaluation. Performance of the various cultivars in the mother trials for the traits of yield, early blight incidence (early season evaluation), early blight severity (late season evaluation), early season stand counts, early season percent flowering or fruiting, vigor, and insect damage (late season evaluation) was evaluated using a fixed model analysis of variance in Minitab 17 (Minitab Inc., State College, PA) using the following model:

$$
\begin{aligned}
y_{\mathrm{ijkl}}= & \mu+\text { Cultivar }_{\mathrm{i}}+\text { Farmer }_{\mathrm{j}}+\text { Cultivar } \\
& \times \text { Farmer }_{\mathrm{ij}}+\operatorname{Rep}_{\mathrm{k}(\mathrm{j})}+e_{\mathrm{ijkl}}
\end{aligned}
$$

Pairwise comparisons were made by a Tukey test with a family-wise error rate of $\alpha=0.1$.

Variance components for mother trial yield and disease incidence and severity were estimated using the lme4 (Bates et al., 2014) package in the $\mathrm{R}$ statistical software (R Core Team, 2015). Variance components were estimated using the following model:

$$
\begin{aligned}
y_{\mathrm{ijkl}}= & \mu+\text { Cultivar }_{\mathrm{i}}+\text { Farmer }_{\mathrm{j}}+\text { Cultivar } \\
& \times \text { Farmer }_{\mathrm{ij}}+\operatorname{Rep}_{\mathrm{k}(\mathrm{j})}+e_{\mathrm{ijkl}}
\end{aligned}
$$

Variance components were calculated for yield, early blight incidence (early season evaluations), and early blight severity (late season evaluations). Early blight disease reaction was selected for calculating variance components as this disease was present in all environments and cultivars, and is a common disease in the region. Heritability was estimated from these models using the equation

$$
\begin{aligned}
h^{2}= & \frac{V_{g}}{\left(V_{g}+\frac{V_{\text {Cultivar:Farmer }}}{\text { No. of Farmers }}\right.} \\
& \left.+\frac{\text { Error }}{\text { No. of farmers }+ \text { No. of Reps }}\right)
\end{aligned}
$$

Differences in baby trial rankings were determined using the Friedman test in SPSS (IBM Corporation, Armonk, NY) with $\alpha=0.05$. Post hoc pairwise comparisons were made using Wilcoxon signed-rank test with a Bonferroni correction for a family-wise error rate of $\alpha=0.05$.

\section{Results}

Tomato production characteristics in the Morogoro Region baseline survey. In the Morogoro Region, 101 respondents ( $72 \%$ male, $28 \%$ female) took part in the surveys (Table 1). Younger farmers (age 18-33) accounted for $30.7 \%$ of the population, whereas middle only once during the trials. (Cotterill, 1987):

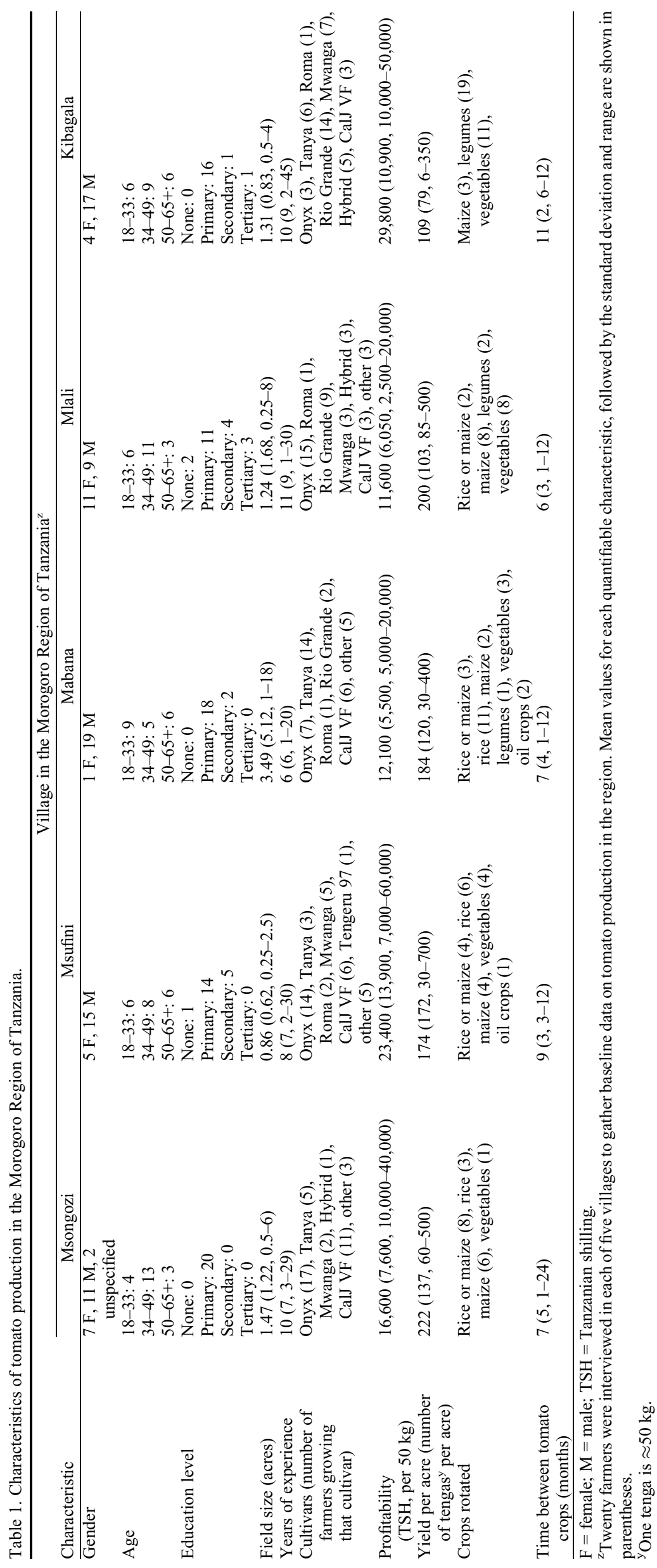

HortScience Vol. 51(12) December 2016 
aged (age 34-49, 45.5\%) and older farmers (age 50+, 23.8\%) accounted for the remainder of the population. Tomato farmers had between 1 and 44 years of experience growing tomatoes, with an average of 8.9 years. Tomatoes were grown on an average of 1.7 acres of land (range $0.25-18$ acres). The most commonly grown tomato cultivars were 'Onyx' (55\% of respondents), 'Cal J' (29\%), 'Tanya' (28\%), 'Rio Grande' (25\%), 'Mwanga' (17\%), various hybrids (9\%), and 'Roma' (5\%). The average time between tomato crops was 8 months. Most farmers included rice or maize $(66 \%$ of respondents) in rotation with tomato, but some farmers also included legumes $(24 \%)$ or other vegetables $(30 \%)$ in their tomato rotations. Farmers viewed the tomato profitability most greatly constrained by diseases $(80 \%$ of respondents), insects (72\%), market access $(57 \%)$, drought $(29 \%)$, and poor seed quality $(20 \%)$. Tomato crop profitability varied between villages, ranging from $\approx 12,000$ Tanzanian shillings $(\approx 6$ U.S. dollar) in Mlali to $\approx 30,000$ Tanzanian shillings $(\approx 15$ U.S. dollar) in Kibagala per $50 \mathrm{~kg}$. Farmer-reported yields were about $10,000 \mathrm{~kg} /$ acre in all villages except in Kibagala, where reported yields were $\approx 5,500 \mathrm{~kg} /$ acre.

The most important tomato cultivar characteristics were reported to be fruit size $(60 \%$ of respondents), transportability (56\%), and keeping quality (53\%). About a quarter of respondents considered disease resistance $(27 \%)$, insect resistance $(25 \%)$, and yield $(22 \%)$ to be important characteristics of tomato cultivars. Fruit shape (17\%), seed availability (9\%), drought tolerance $(5 \%)$, and flavor $(5 \%)$ were less important to farmers. MBT participants $(n=31)$ were also asked which characteristics were most important in a tomato cultivar. The leading characteristics were yield $(77 \%$ of respondents), disease resistance $(68 \%)$, durability of fruit for storage and transport (61\%), insect resistance $(39 \%)$, fruit size $(39 \%)$, drought tolerance (39\%), and fruit color (39\%). Fewer farmers stated that fruit shape $(26 \%)$, marketability (13\%), and fruit quality $(10 \%)$ were important factors in cultivar selection. Other characteristics mentioned included harvest period, growth habit, early maturity, vigor, and seed quality.
Mother trial results. Each mother trial represented a unique environment, with differing management practices and different soil environments (Table 2). In Mabana, only one mother trial was completed due to farmer dropout.

Relative performance of cultivars. The performance of the 10 cultivars included in these trials differed significantly (Table 3 ) in yield, disease reaction, insect damage, vigor, stand count, and percentage of plants flowering or fruiting. A significantly higher percentage of 'OH8243' and 'Assila F' ' plants were flowering or fruiting during the early season assessment than 'Roma', 'Tengeru 97', and 'Tanya' plants. Plots with 'Tanya' had the lowest stand count in the early assessment and had significantly fewer surviving plants than those with 'OH8243', 'Tengeru 97', 'Assila F', and 'Cal J'. 'Tanya' was also the least vigorous cultivar in the early season assessment. Yield per plant of 'OH8243' per plant was significantly higher than yield of 'Mwanga', 'Tanya', 'Onyx', 'Assila $F_{1}$ ', and 'Tengeru 97'. Incidence of early blight was highest for 'Onyx', 'Cal J', and 'Tanya'; these levels were significantly higher than for all other test cultivars. Similarly, early blight severity in 'Cal J', 'Mwanga', and 'Onyx' was significantly higher later in the season than in all other test cultivars. Insect damage was most severe in 'Tengeru 97', significantly higher than in 'Roma', 'OH7870', and 'Assila $\mathrm{F}_{1}$ '.

Variance partitioning and heritability for yield. Variance partitioning was used to assess whether the mother trial design would permit selection based on genetic factors, an important question when considering whether PVS trials can be expanded to include participatory breeding by selecting within segregating material. The variance component for farmer $(n=7$, our measure of environment) accounted for the highest percentage of total variance $(57.03 \%$, Table 4). Cultivar accounted for $8.11 \%$ of the total variance. When adjusted for replication and environment, this variance corresponded to a heritability estimate for yield of 0.74 .

Variance partitioning and heritability for disease reaction. As with yield, the variance component for farmer accounted for the highest percentage of total variance $(49.48 \%)$ for measurements of disease reaction using early blight incidence. Cultivar accounted for $6.08 \%$ of total variance using early blight incidence as a measure of disease resistance, but cultivar accounted for a much higher percentage of variance when using early blight severity as a measure of disease resistance $(26.16 \%)$. Incidence of early blight was more easily measured early in the season when disease severity was low for all diseases, whereas disease severity became a more important measure later in the season as incidence approached $100 \%$ for all cultivars. The heritability estimate for disease reaction as determined by early season measures of early blight incidence was 0.71 , whereas the heritability estimate for disease reaction as determined by a late season measure of early blight severity was 0.90 .

Baby trial results. Among the local tomato cultivars produced in the baby trials, five farmers chose 'Onyx' and five chose 'Tanya' in Mabana. In Msongozi, nine farmers chose 'Onyx' and one chose 'Tanya', while nine produced the cultivar Mwanga and two produced Onyx in Msufini. In responses to the end-of-season survey, 29 of 31 farmers stated that they would produce 'OH7870' again, while 18 would produce 'OH8243'; only 3 farmers stated they would grow 'MT56' again.

Farmers were asked to rank baby trial cultivars for 16 different characteristics (Table 5). From these rankings, we could determine if farmer preference for any of the introduced cultivars differed significantly from that of the preferred local cultivar. On the basis of the Friedman test, there were significant differences between farmers' rankings of cultivars for all characteristics, except for disease levels and fruit quality for eating. The preferred local cultivar ranked significantly better than all introduced cultivars for only three characteristics: fruit quality for marketing, salability, and profitability. The local cultivar was ranked as equivalent to 'OH8243' and 'OH7870', but significantly better than 'MT56' for the characteristics of vigor, ease of management, insect damage, fruit color, and storage quality. 'OH7870' and the local cultivar were ranked as equivalent, but significantly better than 'OH8243' and 'MT56' for harvest period, fruit size, and overall preference. The local

Table 2. Soil characteristics of mother trial sites in Morogoro, Tanzania.

\begin{tabular}{|c|c|c|c|c|c|c|c|}
\hline Site & Msongozi 1 & Msongozi 2 & Msongozi 3 & Msufini 1 & Msufini 2 & Msufini 3 & Mabana 1 \\
\hline$\overline{\mathrm{pH}^{\mathrm{z}}}$ & 6.7 & 6.9 & 6.8 & 6.8 & 7.1 & 7.2 & 6.6 \\
\hline Electrical conductivity ${ }^{z}$ & 0.18 & 0.14 & 0.14 & 0.23 & 0.29 & 0.24 & 0.28 \\
\hline Texture $^{\mathrm{y}}$ & $\begin{array}{c}\text { Sandy clay } \\
\text { loam }\end{array}$ & $\begin{array}{c}\text { Sandy clay } \\
\text { loam }\end{array}$ & $\begin{array}{c}\text { Sandy clay } \\
\text { loam }\end{array}$ & Sandy loam & $\begin{array}{c}\text { Sandy clay } \\
\text { loam }\end{array}$ & Sandy loam & $\begin{array}{c}\text { Sandy clay } \\
\text { loam }\end{array}$ \\
\hline Organic carbon ${ }^{\mathrm{x}}(\%)$ & 3.11 & 2.33 & 2.80 & 2.45 & 2.22 & 2.53 & 1.55 \\
\hline Total nitrogen ${ }^{\mathrm{w}}(\%)$ & 0.2 & 0.14 & 0.16 & 0.14 & 0.15 & 0.16 & 0.14 \\
\hline Phosphorus $^{v}$ (mg/kg) & 42.99 & 11.51 & 13.91 & 19.22 & 67.7 & 70.52 & 8.59 \\
\hline Exchangeable calcium $^{\mathrm{u}}(\mathrm{cmol} / \mathrm{kg})$ & 4.69 & 8.44 & 10.39 & 4.19 & 2.45 & 4.69 & 2.95 \\
\hline Exchangeable magnesium ${ }^{\mathrm{u}}(\mathrm{cmol} / \mathrm{kg})$ & 5.98 & 9.81 & 7.21 & 4.71 & 3.10 & 3.52 & 6.61 \\
\hline Exchangeable potassium $^{\mathrm{u}}(\mathrm{cmol} / \mathrm{kg})$ & 2.81 & 1.31 & 1.84 & 1.53 & 2.59 & 2.81 & 1.4 \\
\hline Exchangeable sodium ${ }^{\mathrm{u}}(\mathrm{cmol} / \mathrm{kg})$ & 0.1 & 0.34 & 0.06 & 0.1 & 0.05 & 0.1 & 0.43 \\
\hline
\end{tabular}

$\mathrm{z}_{1: 2.5}$ in water.

${ }^{\mathrm{y}}$ Bouyoucos hydrometer method (Day, 1965).

${ }^{\mathrm{x}}$ Walkley-Black method (Nelson and Sommers, 1996).

${ }^{\mathrm{w}}$ Modified Kjeldahl method (Wilke, 2005).

${ }^{\mathrm{v}}$ Bray-1 method (Bray and Kurtz, 1945).

${ }^{\mathrm{u}} 1 \mathrm{~m}$ ammonium acetate extractant ( $\mathrm{pH} 7.0$ ) with quantification in an atomic absorption spectrometer (Sumner and Miller, 1996). 
Table 3. Relative performance of cultivars included in mother trials.

\begin{tabular}{|c|c|c|c|c|c|c|c|}
\hline & Yield $^{z y}$ & $\begin{array}{c}\text { Early blight } \\
\text { incidence }{ }^{\mathrm{x}} \text { (early } \\
\text { season evaluation) }\end{array}$ & $\begin{array}{c}\text { Early blight } \\
\text { severity }{ }^{\mathrm{w}} \text { (late } \\
\text { season evaluation) }\end{array}$ & Stand counts ${ }^{v}$ & $\begin{array}{l}\text { Percent flowering } \\
\text { or fruiting }\end{array}$ & Vigor $^{t}$ & $\begin{array}{c}\text { Insect damage }^{\mathrm{s}} \\
\text { (late season evaluation) }\end{array}$ \\
\hline$\overline{\text { Assila F }_{1}}$ & $2.8 \mathrm{de}$ & $33.0 \mathrm{~cd}$ & $6.7 \mathrm{~g}$ & $29.1 \mathrm{a}$ & $79.7 \mathrm{a}$ & $2.8 \mathrm{ab}$ & $6.7 \mathrm{~b}$ \\
\hline Cal J & $4.0 \mathrm{abc}$ & $55.2 \mathrm{a}$ & $23.6 \mathrm{a}$ & $29.0 \mathrm{a}$ & $74.5 \mathrm{abc}$ & $2.7 \mathrm{abc}$ & $7.9 \mathrm{ab}$ \\
\hline Mwanga & $3.7 \mathrm{bc}$ & $51.6 \mathrm{ab}$ & $20.0 \mathrm{ab}$ & $28.5 \mathrm{ab}$ & $73.0 \mathrm{abc}$ & $2.7 \mathrm{abcd}$ & $7.6 \mathrm{ab}$ \\
\hline MT56 & $4.2 \mathrm{ab}$ & $29.9 \mathrm{~cd}$ & $8.3 \mathrm{fg}$ & $28.6 \mathrm{ab}$ & $75.6 \mathrm{ab}$ & $2.5 \mathrm{~cd}$ & $7.1 \mathrm{ab}$ \\
\hline $\mathrm{OH} 8243$ & $4.6 \mathrm{a}$ & $26.1 \mathrm{~d}$ & $11.9 \mathrm{def}$ & $29.3 \mathrm{a}$ & $80.5 \mathrm{a}$ & $2.6 \mathrm{bcd}$ & $7.4 \mathrm{ab}$ \\
\hline OH7870 & $4.1 \mathrm{abc}$ & $35.8 \mathrm{bcd}$ & $9.7 \mathrm{efg}$ & $28.6 \mathrm{ab}$ & $73.0 \mathrm{abc}$ & $2.6 \mathrm{bcd}$ & $6.9 \mathrm{~b}$ \\
\hline Onyx & $3.5 \mathrm{~cd}$ & $59.0 \mathrm{a}$ & $18.2 \mathrm{bc}$ & $28.6 \mathrm{ab}$ & $73.7 \mathrm{abc}$ & $2.6 \mathrm{bcd}$ & $7.4 \mathrm{ab}$ \\
\hline Roma & $4.2 \mathrm{ab}$ & $41.7 \mathrm{abcd}$ & $16.0 \mathrm{bcd}$ & $28.6 \mathrm{ab}$ & $70.9 \mathrm{bc}$ & $2.7 \mathrm{abc}$ & $6.9 \mathrm{~b}$ \\
\hline Tanya & $3.6 \mathrm{bc}$ & $54.6 \mathrm{a}$ & $14.1 \mathrm{cde}$ & $27.6 \mathrm{~b}$ & $67.3 \mathrm{c}$ & $2.4 \mathrm{~d}$ & $7.0 \mathrm{~b}$ \\
\hline Tengeru 97 & $2.6 \mathrm{e}$ & $46.8 \mathrm{abc}$ & $8.3 \mathrm{fg}$ & $29.1 \mathrm{a}$ & $68.1 \mathrm{bc}$ & $2.9 \mathrm{a}$ & $9.0 \mathrm{a}$ \\
\hline
\end{tabular}

${ }^{\mathrm{z}}$ Means for all characteristics were compared using a fixed model analysis of variance with the following model: $y_{\mathrm{ijk} l}=\mu+\mathrm{Cultivar}_{\mathrm{i}}+\mathrm{Farmer}_{\mathrm{j}}+$ Cultivar $\times$ Farmer $_{\mathrm{ij}}+\operatorname{Rep}_{\mathrm{k}(\mathrm{j})}+e_{\mathrm{ijkl}}$. Pairwise comparisons were made using a Tukey test with a family-wise error rate of $\alpha=0.1$; values sharing the same letter are not significantly different.

${ }^{\mathrm{y}}$ Yield is presented in mean kilograms per plant.

${ }^{\mathrm{x}}$ Early blight incidence, as a percentage, is the number of plants exhibiting symptoms of early blight divided by the total number of plants evaluated.

${ }^{\mathrm{w}}$ Early blight severity is the percentage of leaf area affected.

${ }^{\mathrm{v}}$ Stand counts were determined early in the season, the maximum number of plants was 30 .

${ }^{\text {u}}$ Percent flowering or fruiting was determined by counting the number of plants in a plot that were flowering or fruiting divided by the number of plants evaluated.

${ }^{t}$ Vigor was rated on a $1-3$ scale with 1 being the least vigorous and 3 being the most vigorous.

s Insect damage is presented as the percent of leaf area affected.

Table 4. Variance components and percent of total variance for yield and disease reaction from mother trials.

\begin{tabular}{|c|c|c|c|c|c|c|}
\hline \multirow[b]{2}{*}{ Variance component } & \multicolumn{2}{|r|}{ Yield } & \multicolumn{2}{|c|}{ Early blight incidence (early season) } & \multicolumn{2}{|c|}{ Early blight severity (late season) } \\
\hline & Variance & $\begin{array}{c}\text { Percent of } \\
\text { total variance }(\%)\end{array}$ & Variance & $\begin{array}{c}\text { Percent of } \\
\text { total variance }(\%)\end{array}$ & Variance & $\begin{array}{c}\text { Percent of } \\
\text { total variance }(\%)\end{array}$ \\
\hline$\overline{\text { Cultivar }}$ & 0.32 & 8.11 & 114.04 & 6.08 & 29.90 & 26.16 \\
\hline Farmer & 2.25 & 57.03 & 928.75 & 49.48 & 27.62 & 24.16 \\
\hline Cultivar: farmer & 0.33 & 8.41 & 11.76 & 0.63 & 7.46 & 6.52 \\
\hline Rep in farmer & 0.39 & 10.0 & 370.90 & 19.76 & 25.98 & 22.73 \\
\hline Error & 0.65 & 16.46 & 451.48 & 24.05 & 23.34 & 20.42 \\
\hline
\end{tabular}

cultivar was ranked significantly lower than 'OH8243' and 'OH7870' in terms of being harvestable first. The local cultivar was also ranked significantly lower yielding compared with 'OH8243', but ranked equivalent to 'OH7870' for this same characteristic. 'MT56' was ranked significantly better for fruit quality for food preparation than the other three cultivars included in the baby trials, and this was the only characteristic for which 'MT56' was ranked as better than the other cultivars.

Outcome Mapping. We were able to track differences in participation by all boundary partners in the MBT (Table 6). For Msongozi and Msufini, farmers' participation levels remained high throughout the trials, with a slight drop off in participation occurring midseason, but rebounding by the end of the trials. Farmer participation in Mabana was high at the beginning of the season, but decreased as the season progressed, which included the dropout of two farmers managing mother trials. For progress markers that were only assessed once during the season, farmers in all villages met four of six progress markers. Village leader participation was always high in Msongozi, moderate in Msufini, and moderate to low in Mabana. The village leader in Msongozi met seven of nine onetime progress markers, whereas only five and three progress markers were met in Msufini and Mabana, respectively. Extension agent participation was high in Msufini, but extension agents were absent from participation for portions of the trials in both Mabana and Msongozi. Extension agents in Msongozi met none of the onetime progress markers, whereas Msufini extension agents met two markers, and the Mabana extension agent met one marker.

Adoption and dissemination of cultivars. In village, visits completed 1 year after the conclusion of the MBT, farmers continued to grow the introduced cultivars in all three villages. In Msufini, eight of nine farmers interviewed indicated that they had saved seeds and still grew at least one introduced cultivar. In Msongozi, eight of 10 farmers did likewise, whereas in Mabana only three of nine interviewed farmers continued to grow any of the introduced cultivars.

Seven of eight farmers who continued to grow introduced cultivars in Msufini produced 'OH7870', whereas six produced 'OH8243', and three grew 'MT56'. All eight Msufini farmers who grew introduced cultivars distributed seeds to a total of 47 other farmers. Of farmers who received seeds from Msufini MBT participants, 26 received seeds of 'OH7870', 21 of 'OH8243', and only 4 of 'MT56'.

In Msongozi, seven of eight farmers produced ' $\mathrm{OH} 8243$ ' 1 year after participating in the MBT, whereas five continued to produce 'OH7870', and only one grew 'MT56'. Three of these farmers distributed seeds to a total of five other farmers. All of the five farmers received seed of 'OH8243' and three also received 'OH7870', whereas none received 'MT56'.

Of the three Mabana farmers who saved seeds, two grew all three introduced cultivars. In Mabana, no farmers distributed seeds to other farmers. Across the three villages,
'OH7870', 'OH8243', and 'MT56' were produced on an average area of $0.24,0.22$, and 0.14 acre, respectively.

\section{Discussion}

We used the MBT design to introduce and evaluate three cultivars in comparison with established local cultivars. We introduced publicly available, more contemporary tomato germplasm than is currently used in the Morogoro region. We observed a genetic signal using the mother trial design and determined that the introduced material was locally acceptable, indicating that this trial design could also be used in participatory selection and breeding of horticultural crops. The introduced lines performed as well as, and sometimes better than, locally grown cultivars. On the basis of baby trial results, 'OH7870' did not differ significantly from preferred local cultivars in terms of farmers' overall preference. Currently, inbred lines are the best options for Morogoro farmers due to the cost and accessibility of elite hybrids and the limited local seed industry (Afari-Sefa et al., 2011). Older, processing type tomato cultivars, such as 'Rio Grande', 'Roma', or 'Cal J' are the most widely grown in the Morogoro Region of Tanzania. These cultivars lack the disease resistance and vigor of newer, improved tomato cultivars. Disease-resistant hybrids are usually too expensive for growers and may not perform well in the diverse production conditions experienced by smallholders in Morogoro. Introduction of elite inbred germplasm or hybrid cultivars 
Table 5. Ranking of farmers' opinions of different tomato traits.

\begin{tabular}{|c|c|c|c|c|c|c|}
\hline$\overline{\text { Trait }}$ & Best ranking $^{\text {zy }}$ & & & Worst ranking & Friedman test $\left(\chi^{2}\right)$ & Pairwise significant differences \\
\hline $\begin{array}{l}\text { Ease of management (1:easiest } \\
\text { management, } 4 \text { : most difficult to } \\
\text { manage) }\end{array}$ & $\mathrm{OH} 8243^{\mathrm{a}}$ & Local $^{\mathrm{a}}$ & $\mathrm{OH} 7870^{\mathrm{a}}$ & MT56 & $\begin{array}{l}\chi_{3}^{2}=18.29 \\
P<0.0001\end{array}$ & $\begin{array}{l}\text { Local-MT56: }-3.22,0.001 \\
\text { OH8243-MT56: }-3.46,<0.0001 \\
\text { OH7870-MT56: }-3.21,0.001\end{array}$ \\
\hline Yield (1:most yield, 4: least yield) & $\mathrm{OH} 8243$ & $\mathrm{OH} 7870^{\mathrm{a}}$ & Local $^{\mathrm{a}}$ & MT56 & $\begin{array}{l}\chi_{3}^{2}=41.21 \\
P<0.0001\end{array}$ & $\begin{array}{l}\text { Local-OH8243: }-3.51,<0.0001 \\
\text { Local-MT56: }-3.49,<0.0001 \\
\text { OH8243-OH7870: }-3.46,<0.0001 \\
\text { OH8243-MT56: }-4.65,<0.0001 \\
\text { OH7870-MT56: }-2.94,0.003\end{array}$ \\
\hline $\begin{array}{l}\text { Harvest period ( } 1 \text { :longest harvest } \\
\text { period, } 4 \text { : shortest harvest period) }\end{array}$ & Local $^{\text {a }}$ & $\mathrm{OH} 7870^{\mathrm{a}}$ & $\mathrm{OH} 8243^{\mathrm{b}}$ & MT56 ${ }^{\mathrm{b}}$ & $\begin{array}{l}\chi_{3}^{2}=21.47 \\
P<0.0001\end{array}$ & $\begin{array}{l}\text { Local-OH8243: }-2.63,0.007 \\
\text { Local-MT56: }-3.36,<0.0001 \\
\text { OH8243-OH7870: }-2.980 .002 \\
\text { OH7870-MT56: }-3.56,<0.0001\end{array}$ \\
\hline $\begin{array}{l}\text { Fruit quality for eating (1: best } \\
\text { quality, } 4 \text { : worst quality) }\end{array}$ & OH8243 & Local & MT56 & OH7870 & $\begin{aligned} \chi_{3}^{2} & =1.45 \\
P & =0.705\end{aligned}$ & N/A \\
\hline $\begin{array}{l}\text { Fruit quality for food preparation } \\
\text { (1: best quality, } 4 \text { : worst quality) }\end{array}$ & MT56 & $\mathrm{OH} 8243^{\mathrm{a}}$ & Local $^{\mathrm{a}}$ & $\mathrm{OH} 7870^{\mathrm{a}}$ & $\begin{array}{l}\chi_{3}^{2}=29.13 \\
P<0.0001\end{array}$ & $\begin{array}{l}\text { Local-MT56: }-3.60,<0.0001 \\
\text { OH8243-MT56: }-2.98,0.002 \\
\text { OH7870-MT56, }-3.86,<0.0001\end{array}$ \\
\hline $\begin{array}{l}\text { Fruit quality for marketing (1: best } \\
\text { quality, } 4 \text { : worst quality) }\end{array}$ & Local & $\mathrm{OH} 7870$ & OH8243 & MT56 & $\begin{array}{l}\chi_{3}^{2}=71.25 \\
P<0.0001\end{array}$ & $\begin{array}{l}\text { Local-OH8243: }-4.86,<0.0001 \\
\text { Local-OH7870: }-3.37,0.001 \\
\text { Local-MT56: }-5.12,<0.0001 \\
\text { OH8243-OH7870: }-3.02,0.002 \\
\text { OH8243-MT56: }-4.63,<0.0001 \\
\text { OH7870-MT56: }-4.63,<0.0001\end{array}$ \\
\hline $\begin{array}{l}\text { Salability (1: most likely to sell, } \\
\text { 4: least likely to sell) }\end{array}$ & Local & $\mathrm{OH} 7870$ & OH8243 & MT56 & $\begin{array}{l}\chi_{3}^{2}=73.14 \\
P<0.0001\end{array}$ & $\begin{array}{l}\text { Local-OH8243: }-5.00,<0.0001 \\
\text { Local-OH7870: }-3.02,0.002 \\
\text { Local-MT56: }-5.07,<0.0001 \\
\text { OH8243-OH7870: }-3.68,<0.0001 \\
\text { OH8243-MT56: }-4.67,<0.0001 \\
\text { OH7870-MT56: }-4.67,<0.0001\end{array}$ \\
\hline $\begin{array}{l}\text { Profitability (1: highest price, } \\
\text { 4: lowest price) }\end{array}$ & Local & OH7870 & $\mathrm{OH} 8243$ & MT56 & $\begin{array}{l}\chi_{3}^{2}=74.50 \\
P<0.0001\end{array}$ & $\begin{array}{l}\text { Local-OH8243: }-4.63,<0.0001 \\
\text { Local-OH7870: }-3.86,<0.0001 \\
\text { Local-MT56: }-5.20,<0.0001 \\
\text { OH8243-OH7870: }-3.20,0.001 \\
\text { OH8243-MT56: }-4.57,<0.0001 \\
\text { OH7870-MT56: }-4.95,<0.0001\end{array}$ \\
\hline $\begin{array}{l}\text { Overall preference (1: most } \\
\text { preferred, } 4: \text { least preferred })\end{array}$ & Local $^{\mathrm{a}}$ & $\mathrm{OH} 7870^{\mathrm{a}}$ & OH8243 & MT56 & $\begin{array}{l}\chi_{3}^{2}=63.81 \\
P<0.0001\end{array}$ & $\begin{array}{l}\text { Local-OH8243: }-4.16,<0.0001 \\
\text { Local-MT56: }-4.99,<0.0001 \\
\text { OH8243-OH7870: }-3.21,0.001 \\
\text { OH8243-MT56: }-4.31,<0.0001 \\
\text { OH7870-MT56: }-4.83,<0.0001\end{array}$ \\
\hline
\end{tabular}

${ }^{\mathrm{z} O p i n i o n s ~ w e r e ~ r a n k e d ~ o n ~ a ~} 1-4$ scale (best to worst, no ties allowed) and the Friedman test $(\alpha=0.05)$ was used to identify significant differences between farmers rankings. Pairwise comparisons were made using Wilcoxon signed-rank test with a Bonferroni correction for a family-wise error rate of $\alpha=0.05$.

${ }^{\mathrm{y}}$ Cultivars sharing the same superscript letter are not significantly different from each other based on the Wilcoxon signed-rank test with a family-wise error rate of $\alpha=0.05$.

through MBT could increase tomato productivity, especially given the diversification and growth of various 'Roma' tomato breeding programs. The use of inbred lines is the only current option that allows for local dissemination of cultivars.
In PVS, farmers evaluate established cultivars and select from these cultivars, yet the MBT design may also be appropriate in a PPB approach to advance tomato germplasm and breed-improved cultivars. Even though environment accounted for a large proportion of the total variance, cultivar still accounted for enough variance to allow for future selection for yield and disease reaction. Heritability estimates for yield and disease reaction were relatively high, which indicates that progress in these traits could quickly be made following 
Table 6. Outcome Mapping scores for progress markers in each village in Morogoro, Tanzania.

\begin{tabular}{|c|c|c|c|c|c|c|c|c|c|}
\hline & \multicolumn{3}{|c|}{ Msongozi $^{\mathrm{z}}$} & \multicolumn{3}{|c|}{ Msufini } & \multicolumn{3}{|c|}{ Mabana } \\
\hline & Farmers & $\begin{array}{l}\text { Village } \\
\text { leaders }\end{array}$ & $\begin{array}{c}\text { Extension } \\
\text { agents }\end{array}$ & Farmers & $\begin{array}{l}\text { Village } \\
\text { leaders }\end{array}$ & $\begin{array}{c}\text { Extension } \\
\text { agents }\end{array}$ & Farmers & $\begin{array}{l}\text { Village } \\
\text { leaders }\end{array}$ & $\begin{array}{c}\text { Extension } \\
\text { agents }\end{array}$ \\
\hline Early season & 3 & 3 & 2.45 & 3 & 2.6 & 2.82 & 3 & 2 & 1.36 \\
\hline Mid season & 2.89 & 3 & 1.13 & 2.89 & 2 & 3 & 2.44 & 1.2 & 1 \\
\hline Late season & 3 & 3 & 1 & 3 & 2.6 & 3 & 2.33 & 1.2 & 3 \\
\hline Onetime markers & 4 & 7 & 0 & 4 & 5 & 2 & 4 & 3 & 1 \\
\hline
\end{tabular}

${ }^{\mathrm{z}}$ Progress markers for participation were evaluated three times during the trials (early, middle, and late) and participation was evaluated at being low (1), moderate (2), or high (3), and the average participation level is shown for each boundary partner. Onetime progress markers were assessed only once in the trials and the number of markers observed is listed. For farmers, there were six onetime markers, nine for village leaders, and four for extension agents.

the introduction of new germplasm. Resources can be limited in PPB studies (Afari-Sefa et al., 2011), and variance components can be used to adjust the design of mother trials to maximize selection efficiency while using the same resources (Sacks and Francis, 2001). As suggested by the results of our mother trials, this could be accomplished by increasing the number of environments (farmers), reducing the number of replications within mother trials, and increasing the number of cultivars tested.

The MBT design may also allow for a unique hybrid of PVS and PPB, with breeders selecting from germplasm in mother trials, while simultaneously gaining insight on the acceptability of specific cultivar traits from farmers in baby trials. In Tanzania, farmer input was used in the evaluation of late blightresistant tomato cultivars (Ojiewo et al., 2011), and the MBT allows for an expansion of the feedback that farmers provide. The MBT design would be a powerful tool to conduct future PVS trials for tomato and other horticultural crops as it allows for the linkage of quantitative and qualitative evaluations of tomatoes, subjects cultivars to more diverse environments, and provides farmers with experience with introduced cultivars.

Our use of rankings in the baby trial evaluations identified several traits for which our test cultivars were equivalent or superior to locally grown cultivars. Rankings are adequate to determine how the test cultivars are performing compared with the farmerselected "ideal" local cultivar. If baby trials do not include a control cultivar or researchers also want to determine if the local cultivar is itself adequate, ratings may be a more appropriate means to evaluate cultivar performance (Coe, 2002). Although both ranking and rating data from farmers are valuable in evaluating cultivars, the value of this data are strengthened when combined with farmer interviews. For example, while 'OH8243' was highly ranked by our farmers on many characteristics, farmers did not rank it as highly overall as the local cultivar and ' $\mathrm{OH} 7870$ ' because its fruit size was not large enough, and fruit size is a key characteristic for Morogoro farmers when choosing tomato cultivars. 'MT56' was rated poorly for nearly every characteristic, except for food quality for food preparation. Farmers repeatedly said 'MT56' was a superior cultivar for making kachumbari, a very common tomato dish in Tanzania. Bacterial wilt, to which 'MT56' is moderately resistant, did not occur in these trials; farmer ranking for this cultivar may have been different had the disease occurred and caused losses in the other cultivars, all of which are susceptible to bacterial wilt.

MBTs are usually conducted in multiple location trials and a means to evaluate participation by farmers and other stakeholders at these sites is necessary to coordinate research efforts and predict long-term success of the trials. We used Outcome Mapping to evaluate farmers, village leaders, and extension agents (Testen et al., 2016). Participation of farmers, the extension agent, and the village leader was moderate to high in Msufini. More farmers in this village continued to grow introduced test cultivars and distribute seeds from these cultivars to other farmers 1 year following the end of the trials than in other participating villages. Participation of farmers and the village leader, but not the extension agent, was good in Msongozi. In this village, many farmers continued to grow introduced cultivars, but few farmers distributed seeds to other farmers. Participation of all stakeholders in Mabana was low to moderate, farmer adoption of test cultivars was low, and none of the farmers distributed introduced cultivars within the village. On the basis of our initial Outcome Mapping findings, we predicted that farmers in Msongozi and Msufini would demonstrate the highest levels of adoption of the test cultivars, and that those in Mabana would have the lowest. Outcome Mapping allowed us to identify issues with participation in real time, and could be used to track multiple trial locations for MBT.

We provided a framework for using the MBT design for PVS and PPB of horticultural crops in developing countries. Important aspects of this framework were pretrial surveys, the design of MBTs, and trial evaluation using Outcome Mapping. The pretrial surveys allowed us to identify villages conducive to trials and identify key local cultivars and crop characteristics for Morogoro farmers. The MBT design is appropriate for PPB, because a genetic signal was detectable in mother trials, even when a small population of cultivars and few environments were evaluated. The acceptability of introduced cultivars is demonstrated in baby trials. The success of MBT hinges on the interactions of farmers, extension agents, and village leaders, and Outcome Mapping can be used to indicate which villages are conducive to adoption and dissemination of acceptable cultivars. This framework could be used to successfully implement PCI trials for other horticultural crops in developing countries.

\section{Literature Cited}

Adeniji, O.T. and A. Aloyce. 2012. Farmer's knowledge of horticultural traits and participatory selection of African eggplant varieties (Solanum aethiopicum) in Tanzania. Tropicultura 30:185-191.

Adeniji, O.T. and A. Aloyce. 2013. Farmers' participatory identification of horticultural traits: Developing breeding objectives for vegetable amaranth in Tanzania. J. Crop Improv. 27: 309-318.

Adeniji, O.T. and A. Aloyce. 2014. Participatory identification of agronomic and leaf quality traits in Ethiopian mustard (Brassica carinata A. Braun) genotypes in Tanzania. Agr. Biol. J. N. Am. 5:245-251.

Adeniji, O.T., I. Swai, M.O. Oluoch, R. Tanyongana, and A. Aloyce. 2010. Evaluation of head yield and participatory selection of horticultural characters in cabbage (Brassiva olearaceae var. capitata). J. Plant Breed. Crop Sci. 2:243-250.

Afari-Sefa, V., A. Tenkouano, C.O. Ojiewo, J.D.H Keatinge, and J.d'A. Hughes. 2011. Vegetable breeding in Africa: Constraints, complexity and contributions toward achieving food and nutritional security. Food Secur. 4:115-127.

Akinnifesi, F.K., F.R. Kwesiga, J. Mhango, A. Mkonda, T. Chilanga, and R. Swai. 2004. Domesticating priority miombo indigenous fruit trees as a promising livelihood option for small-holder farmers in southern Africa. Acta Hort. 632:15-30.

Almekinders, C.J.M. and A. Elings. 2001. Collaboration of farmers and breeders: Participatory crop improvement in perspective. Euphytica 122: 425-438.

Asiimwe, D., G. Tusiime, J. Karungi, S. Kyamanywa, S.A. Miller, and P.R. Rubaihayo. 2013. Comparison of the reaction of MT56 with other popular tomato genotypes to bacterial wilt in six locations in Uganda. Afr. Crop Sci. Conf. Proc. 11: 203-209.

Atlin, G., T. Paris, and B. Courtois. 2002. Sources of variation in participatory varietal selection trials with rainfed rice: Implications for the design of mother and baby trial networks, $p$. 36-43. In: M.R. Bellon and J. Reeves (eds.). Quantitative analysis of data from participatory methods in plant breeding. CIMMYT, Mexico.

Bänzinger, M. and A. Diallo. 2004. Progress in developing drought and $\mathrm{N}$ stress tolerant maize cultivars for eastern and southern Africa, $\mathrm{p}$. 189-194. In: Integrated approaches to higher maize productivity in the new millennium. Proc. 7th Eastern and Southern Africa Regional Maize Conf.. CIMMYT/KARI, Nairobi, Kenya.

Bates, D., M. Mächler, B. Bolker, and S. Walker. 2014. Fitting linear mixed-effects models using lme4. arXiv: 1406.5823

Belay, G., H. Tefera, B. Tadesse, G. Metaferia, D. Jarra, and T. Tadesse. 2006. Participatory variety selection in the Ethiopian cereal tef (Eragrostis tef). Exp. Agr. 42:91-101. 
Berry, S.Z. and W.A. Gould. 1982. "Ohio 7870" tomato. HortScience 17:226-267.

Berry, S.Z. and W.A. Gould. 1988. "Ohio 8243" processing tomato. HortScience 23:930.

Bray, R.H. and L.T. Kurtz. 1945. Determination of total, organic, and available forms of phosphorus in soils. Soil Sci. 59:39-46.

Bucheyeki, T.L., E.M. Shenkalwa, T.X. Mapunda, and L.W. Matata. 2010. Yield performance and adaptation of four sorghum cultivars in Igunga and Nzega districts of Tanzania. Commun. Biometry Crop Sci. 5:4-10.

Coe, R. 2002. Analyzing ranking and rating data from participatory on-farm trials, p. 44-65. In: M.R. Bellon and J. Reeves (eds.). Quantitative analysis of data from participatory methods in plant breeding. CIMMYT, Mexico.

Cotterill, P.P. 1987. Short Note: On estimating heritability according to practical applications. Silvae Genet. 36:46-48.

Day, P.R. 1965. Particle fractionation and particlesize analysis, p. 545-567. In: Methods of soil analysis. Part 1: Physical and mineralogical properties. Agronomy Monograph 9.1.

Diouf, M., A. Kanté, and N.B. Mbengue. 2007. African leafy vegetables-Agromorphological characterization and participatory plant breeding on four species. Acta Hort. 752:175-178.

Earl, S., F. Carden, and T. Smutylo. 2001. Outcome Mapping: Building learning and reflection into development programs. International Development Research Center, Ottawa, Canada.

Hillocks, R.J., C.S. Madata, R. Chirwa, E.M. Minja, and S. Msolla. 2006. Phaseolus bean improvement in Tanzania, 1959-2005. Euphytica 150. 215-231.

Kafiriti, E.M., S. Dondeyne, S. Msomba, J.A. Deckers, and D. Raes. 2003. Variations in agronomic characteristics of irrigated rice varieties: Lessons from participatory trials in southeastern Tanzania. Food Agr. Environ. 1:273-277.

Kitch, L.W., O. Boukar, C. Endondo, and L.L. Murdock. 1998. Farmer acceptability criteria in breeding cowpea. Exp. Agr. 34:475-486.

Kundy, A.C., G.S. Mkamilo, and R.N. Misangu. 2014. Assessment and selection of superior genotypes among elite cassava genotypes by farmers and scientists in southern Tanzania. J. Nat. Sci. Res. 4:24-32.

Leakey, R.R.B., K. Schreckenberg, and Z. Tchoundjeu. 2003. The participatory domestication of West African indigenous fruits. Int. For. Rev. 5:338-347.

Maerere, A.P., K.P. Sibuga, J.E.M. Bulali, M.W. Mwatawala, J. Kovach, S. Kyamanywa, H.D.
Mtui, and M. Erbaugh. 2010. Deriving appropriate pest management technologies for smallholder tomato (Solanum lycopersicum Mill.) growers: A case study of Morogoro, Tanzania. J. Anim. Plant Sci. 6:663-676.

Maerere, A.P., K.P. Sibuga, K.K. Mwajombe, J. Bulali, M.N. William, L. Mwinyipembe, J. Mbwambo, and J. Shayo. 2006. Baseline survey report of tomato production in Mvomero District, Morogoro Region, Tanzania, Regional IPM Program for East Africa: Kenya, Tanzania and Uganda. Morogoro, Tanzania.

Masumba, E.A., H. Kulembeka, S.M. Tollano, and M. Yongolo. 2005. Participatory evaluation of improved sweetpotato varieties in eastern Tanzania. Afr. Crop Sci. J. 12:259-265.

McElhinny, E., E. Peralta, N. Mazón, D.L. Danial, G. Thiele, and P. Lindhout. 2006. Aspects of participatory plant breeding for quinoa in marginal areas of Ecuador. Euphytica 153:373-384.

Minja, R.R., J. Ambrose, A. Ndee, I.S. Swai, and C.O. Ojiewo. 2011. Promising improved tomato varieties for eastern Tanzania. Afr. J. Hort. Sci. 4:24-30.

Nelson, D.W. and L.E. Sommers. 1996. Total carbon, organic carbon, and organic matter, $p$ 961-1010. In: D.L. Sparks (ed.). Methods of Soil Analysis, Part 3. Chemical methods. Soil Science Society of America Book Series 5. American Society of Agronomy, Madison, WI

Ojiewo, C.O., I.S. Swai, M.O. Oluoch, D. Silue, R. Nono-Womdim, P. Hanson, L. Black, and T.C. Wang. 2011. Participatory cultivar evaluation, selection, and release of late blight resistant tomato cultivars in Tanzania. Acta Hort. 911:199-206.

Osiru, M.O., E.S. Monyo, F. Waliyar, B Chinyamunyama, O. Mponda, and M. Siambi 2009. Participatory development of improved groundnut varieties for east and southern Africa. Agr. Innov. Sustain. Dev. 1:35-40.

Paavola, J. 2008. Livelihoods, vulnerability and adaptation to climate change in Morogoro, Tanzania Environ. Sci. Policy 11:642-654.

Pandey, Y.R., A.B. Pun, and K.P. Upadhyay. 2006. Participatory varietal evaluation of rainy season tomato under plastic house condition. Nepal Agr. Res. J. 7:11-15.

Ponte, S. 1998. Fast crops, fast cash: Market liberalization and rural livelihoods in Songea and Morogoro Districts, Tanzania. Can. J. Afr. Stud. Rev. Can. Études Afr. 32:316-348.

R Core Team. 2015. R: A language and environment for statistical computing.

Sacks, E.J. and D.M. Francis. 2001. Genetic and environmental variation for tomato flesh color in a population of modern breeding lines. $\mathrm{J}$. Amer. Soc. Hort. Sci. 126:221-226.

Shiferaw, B.A., T.A. Kebede, and L. You. 2008. Technology adoption under seed access constraints and the economic impacts of improved pigeonpea varieties in Tanzania. Agr. Econ. 39:309-323.

Snapp, S. 1999. Mother and baby trials: A novel trial design being tried out in Malawi. TARGET Newsl. Soil Fertil. Res. Netw. Maize-Based Crop. Syst. Malawi, Zimbabwe.

Snapp, S., G. Kanyama-Phiri, B. Kamanga, R. Gilbert, and K. Wellard. 2002. Farmer and researcher partnerships in Malawi: Developing soil fertility technologies for the near-term and far-term. Exp. Agr. 38:411-431.

Sperling, L., M.E. Loevinsohn, and B. Ntabomvura. 1993. Rethinking the farmer's role in plant breeding: Local bean experts and on-station selection in Rwanda. Exp. Agr. 29:509-519.

Sumner, M.E. and W.P. Miller. 1996. Cation exchange capacity and exchange coefficients, $p$. 1201-1229. In: D.L. Sparks (ed.). Methods of soil analysis, Part 3. Chemical methods. Soil Science Society of America Book Series 5. American Society of Agronomy, Madison, WI.

Testen, A.L., D.P. Mamiro, J. Nahson, H.D. Mtui, and S.A. Miller. 2016. Evaluation of plant health programs using Outcome Mapping. Plant Health Progress. (In press).

Thiele, G., G. Gardner, R. Torrez, and J. Gabriel 1997. Farmer involvement in selecting new varieties: Potatoes in Bolivia. Exp. Agr. 33: 275-290.

Waal, D.D., F.R. Chinjinga, L. Johansson, F.F. Kanju, and N. Nathaniels. 1997. Village-based cassava breeding in Tanzania, p. 83-88. In: L.V. Veldhuizen (ed.). Farmers' research in practice: Lessons from the field. Intermediate Technology Publications, London.

Wilke, B.M. 2005. Determination of chemical and physical soil properties, p. 47-95. In: R. Margesin and F. Schinner (ed.). Monitoring and assessing soil bioremediation, soil biology. Springer, Heidelberg, Berlin

Witcombe, J.R., K.D. Joshi, S. Gyawali, A.M. Musa, C. Johansen, D.S. Virk, and B.R. Sthapit. 2005. Participatory plant breeding is better described as highly client-oriented plant breeding I. Four indicators of client-orientation in plant breeding. Exp. Agr. 41:299-319.

Witcombe, J.R., R. Petre, S. Jones, and A. Joshi. 1999. Farmer participatory crop improvement. IV. The spread and impact of a rice variety identified by participatory varietal selection. Exp. Agr. 35:471-487. 